\title{
Permian plants from the Chutani Formation (Titicaca Group, northern Altiplano of Bolivia): II. The morphogenus Glossopteris
}

\author{
ROBERTO IANNUZZI ${ }^{1}$, CARLOS E. L. VIEIRA ${ }^{1}$, MARGOT GUERRA-SOMMER ${ }^{1}$, \\ ENRIQUE DÍAZ-MARTÍNEZ ${ }^{2}$ and GEORGE W. GRADER ${ }^{3}$ \\ ${ }^{1}$ Departamento de Paleontologia e Estratigrafia, Instituto de Geociências, UFRGS \\ Cx. Postal 15.001, 91501-970 Porto Alegre, RS, Brasil \\ ${ }^{2}$ Centro de Astrobiología (CSIC-INTA), Carretera a Ajalvir, km 4, 28850 Torrejón de Ardoz, Madrid, Spain \\ ${ }^{3}$ Department of Geology, University of Idaho, Moscow, ID, 83844-3022 U.S.A.
}

Manuscript received on February 27, 2003; accepted for publication on October 1, 2003; presented by Diogenes A. CAMPos

\begin{abstract}
Fossil plants belonging to the morphogenera Glossopteris, Pecopteris and Asterotheca were collected from the upper part of the Chutani Formation (Titicaca Group), near the town of San Pablo de Tiquina, on the southeastern shore of Lake Titicaca (northern Altiplano, Bolivia). This paper presents the first description of specimens of the morphogenus Glossopteris from Bolivia. The Bolivian specimens of Glossopteris consist of poorly-preserved impressions, although they present the diagnostic features of this morphogenus. They are fragments of leaves with secondary veins of taeniopterid-type, typical of glossopterids from Late Permian deposits of Gondwana. The only species of Pecopteris confirmed in the first part of this study, i.e. P. dolianitii Rösler and Rohn (see Vieira et al. 2004), was previously reported from the Late Permian beds of the Rio do Rasto and Estrada Nova formations in the Paraná Basin (southern Brazil). Therefore, a Late Permian age is proposed for the fossil plant-bearing beds of the Chutani Formation based on the analyzed assemblage. The phytogeographic implications of this new find are briefly analyzed.
\end{abstract}

Key words: Altiplano of Bolivia, Permian, Glossopteris, phytogeography.

\section{INTRODUCTION}

The presence of the morphogenus Glossopteris in Bolivia had already been mentioned in the literature (Archangelsky 1984, 1986). However, none of the published syntheses on Bolivian Paleozoic floras mentions this floristic element (Suárez-Soruco 1974, Archangelsky 1993). Furthermore, the latest review affirms that, so far, there has not been any description of glossopterid plants from Bolivia (Archangelsky 1993). Consequently, this second

Correspondence to: Roberto Iannuzzi

E-mail: roberto.iannuzzi@ufrgs.br part of the report on the fossil plants from the Chutani Formation presents, for the first time, a description of Bolivian specimens of the morphogenus Glossopteris. The new findings prove the floral connection and similarities between western Gondwana, represented by the Central Andean region (Peru-Bolivia basin), and other parts of the megacontinent.

\section{MATERIALS AND METHODS}

In 1996, three of the authors (RI, EDM, GWG) collected fossil plants belonging to the morphogenera 
Glossopteris, Pecopteris and Asterotheca. The fossils were found NE of San Pablo de Tiquina, a small town on the SE shore of Lake Titicaca (western Bolivia), where ferryboats cross the Strait of Tiquina to the Copacabana Peninsula. The fossil site is located approximately $80 \mathrm{~m}$ up-hill from the town's cemetery (for a location map see Vieira et al. 2004). The studied samples were collected from the upper part of the Chutani Formation (Titicaca Group - geological setting in Vieira et al. 2004). The fronds of Pecopteris and Asterotheca have been described by Vieira et al. (2004) and form the first part of this study. The leaves of Glossopteris were found as impressions on brownish yellow, hard, compact, silty dolostone. The specimens are fragmentary and stained by iron oxide. The impressions are usually unclear and we had difficulties to photograph them. All studied specimens are listed below and housed at the Museu de Paleontologia of the Departamento de Paleontologia e Estratigrafia of the Universidade Federal do Rio Grande do Sul (code prefix MP-Pb).

\section{SYSTEMATIC RESULTS}

\section{Class GYMNOSPERMOPSIDA}

Order GLOSSOPTERIDALES

Genus Glossopteris Brongniart 1828

Glossopteris cf. G. occidentalis White 1908 Figs. 1A, 2A, 3

\section{Material: MP-Pb 3576A/B, 3579A/B}

Description: The specimen MP-Pb 3576 is the best preserved and represents a middle portion of a fragmentary leaf. The incomplete specimen is $8.1 \mathrm{~cm}$ long and approximately $5.32 \mathrm{~cm}$ wide. The shape of the leaf cannot be deduced, but it shows parallel lateral margins. The midrib is distinct, about $6.7 \mathrm{~mm}$ wide, and composed of a bundle of thick parallel veins (at least 7 or 8), with rare connecting veins. The venation pattern is taeniopteroid: secondary veins arise from the midrib at acute angles $\left(20-22^{\circ}\right)$, but they immediately take a sharp bend and follow a straight and parallel course at angles of $80-85^{\circ}$ to the midrib, near the leaf margin they incline towards the apex, reaching the margin at angles of $65-70^{\circ}$. There are about $28-30$ secondary veins per $\mathrm{cm}$ half way across the lamina. The pattern of meshes is not well preserved, but apparently the secondary veins show rare and irregularly distributed oblique anastomoses, dichotomizing few times (5 at least) to form short and fusiform meshes near midrib and narrow-elongate ones for the remainder of the lamina.

Comparison: The veining pattern agrees closely with the following species: Glossopteris ampla Dana as described by Archangelsky (1958); G. damudica Feistmantel by Maheshwari and Prakash (1965), Chandra and Singh (1992); G. gigas Pant and Singh by Chandra and Singh (1992); G. occidentalis White by White (1908); G. taeniopteroides Feistmantel by Feistmantel (1878), Maheshwari (1965) and Rohn and Rösler (1989); and G. waginanus (Rigby) Rigby, Chandra and Surange by Rigby (1966) and Rigby et al. (1988), respectively. Width of leaf and midrib, venation density (veins per $\mathrm{cm}$ ), frequency of anastomoses (number of meshes between midrib and margin), and pattern of meshes, are comparatively more related to G. occidentalis and $G$. damudica. However, the latter differs from the Bolivian specimens in terms of general inclination of secondary veins which arise at obtuse angles. Further morphological details such as shape and size of leaf, and pattern of meshes along the complete leaf, are still required to obtain a more precise determination.

Glossopteris sp. 1

Figs. 1B, 2B, 2C, 4

Material: MP-Pb 3577A/B, 3578, 3580, 3581, $3582,3583,3584,3585$

Description: There are a few well-preserved specimens in the present collection. Amongst them, specimen MP-Pb 3577A is the most complete. This specimen represents a long (13.4 cm preserved) and narrow $(1.74 \mathrm{~cm}$ maximum width) fragmentary leaf of unknown base, tapering gently and distally to an acute apex. Midrib strong, $4 \mathrm{~mm}$ broad (max.), persistent up to the leaf apex, composed initially of six 


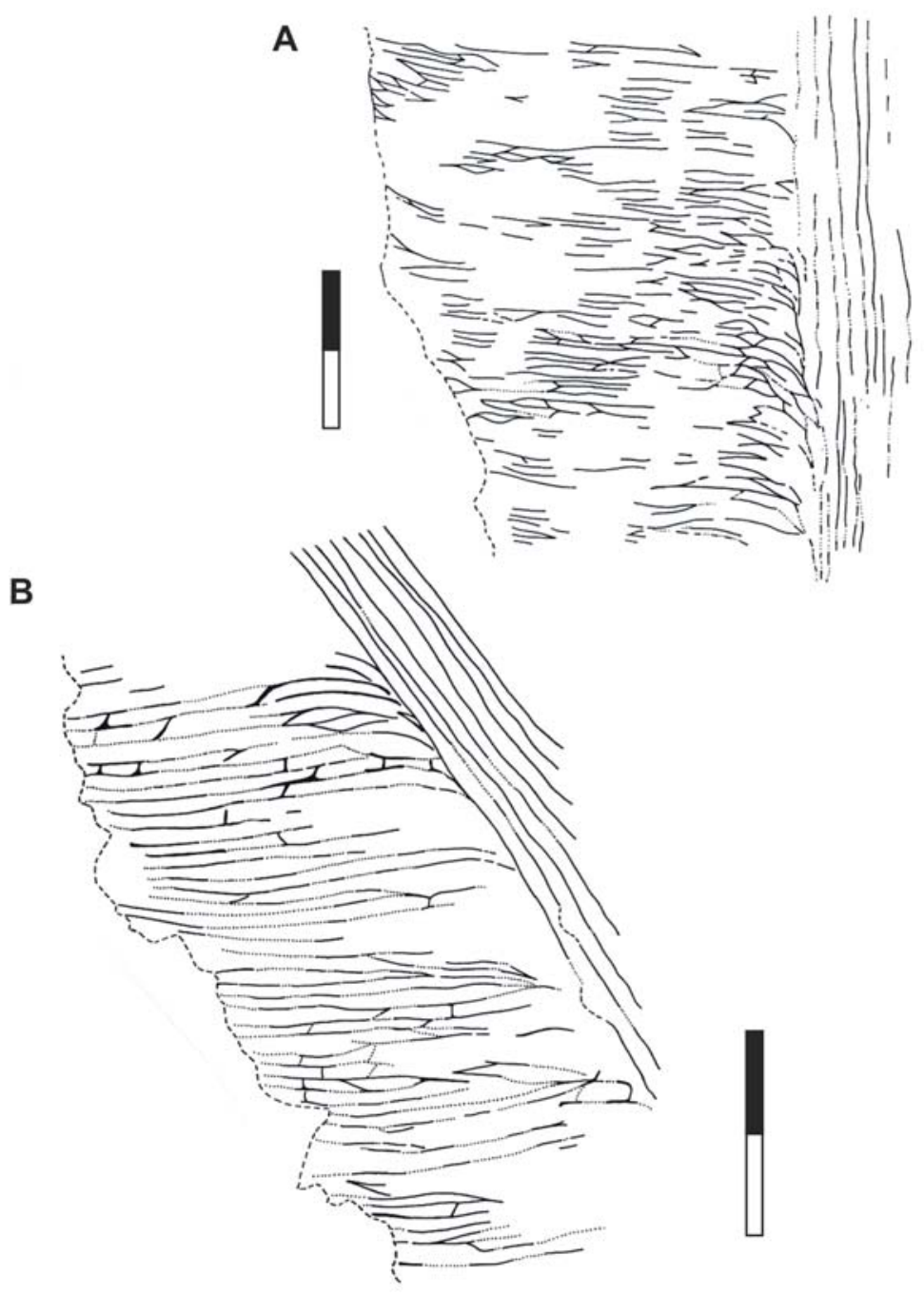

Fig. 1 - Drawings of described Glossopteris leaves: (A) specimens of Glossopteris cf. G. occidentalis White [MP-Pb 3576A] and (B) Glossopteris sp. 1 [MP-Pb 3577A] showing a middle portion of the leaf with prominent and thick midrib and taeniopteroid venation, respectively. Continuous line $=$ outline preserved; dotted line $=$ outline poorly preserved; chain line $=$ outline broken. Scale bars: $(A)=1.0 \mathrm{~cm} ;(B)=0.5 \mathrm{~cm}$.

thick parallel veins at the base, immediately reducing to four veins and gradually contracting towards the apex where it becomes resolved in finer veins. Taeniopteroid veining pattern, secondary veins leave the midrib at narrow $\left(22-35^{\circ}\right)$ to broad $\left(55-65^{\circ}\right)$ acute angles and, after a gentle arch, pass straight, parallel inclined at $55-65^{\circ}$ to the midrib, reaching the margin at about $55^{\circ}$. The secondary veins often show irreg- ularly distributed perpendicular and oblique anastomoses, dichotomizing several times (10 at least). The concentration of veins is approximately 25-30 per $\mathrm{cm}$ in the middle part of the lamina. The meshes vary from elongate to short, polygonal to fusiform in shape, alternating irregularly between long and short ones across the lamina.

The specimen MP-Pb 3580 represents a middle 

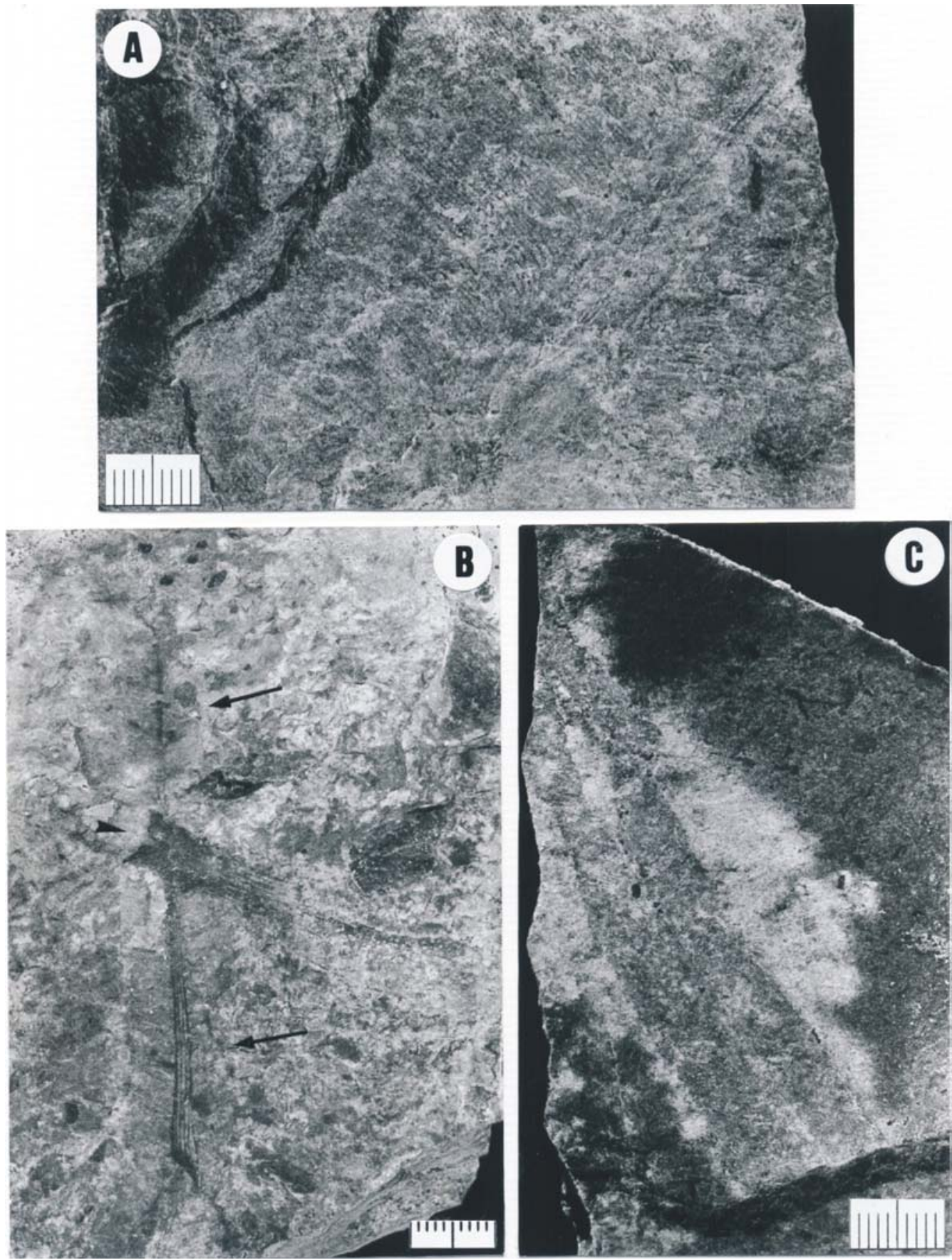

Fig. 2 - Photos of Glossopteris leaves: (A) Glossopteris cf. G. occidentalis White [MP-Pb 3576A] showing a middle portion of the leaf; (B) specimens of Glossopteris sp. 1 showing almost a complete leaf [MP-Pb 3577A - two longest arrows] and base of the leaf [MP-Pb 3577B - shortened arrow]; (C) Glossopteris sp. 1 showing the middle part and top of the leaf [MP-Pb 3585A]. Scale bars: $1.0 \mathrm{~cm}$. 


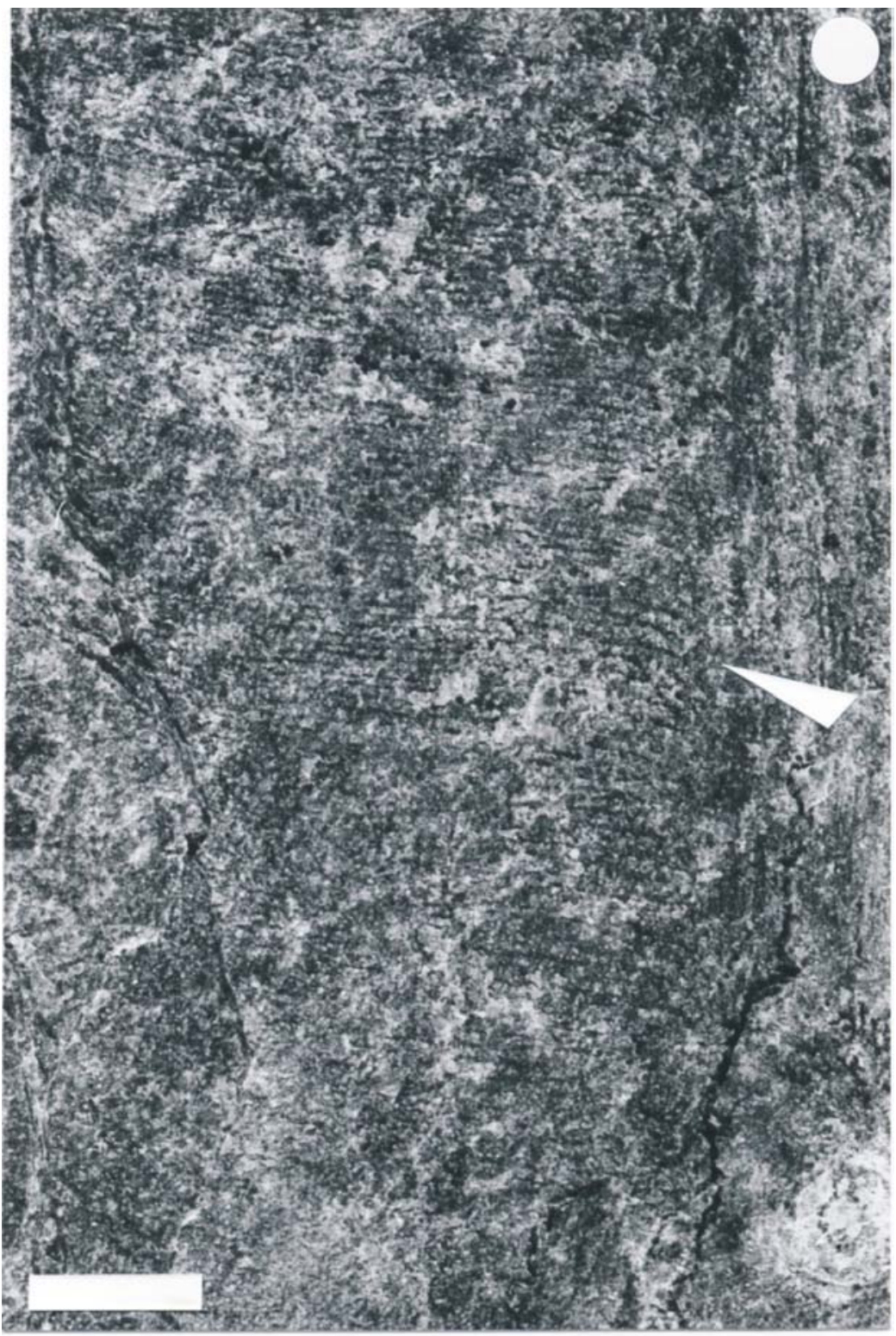

Fig. 3 - Part of the leaf illustrated in Fig. 2 (A) [MP-Pb 3576A] enlarged to show details of taeniopteroid venation (arrow). Scale bars: $0.5 \mathrm{~cm}$.

portion of the incomplete leaf and measures $3.4 \mathrm{~cm}$ in length and about $14.6 \mathrm{~mm}$ in width. The fragmentary leaf shows parallel lateral margins, a distinctive midrib with $2.6 \mathrm{~mm}$ in width, and is composed of a bundle of poorly preserved parallel veins. The veining pattern is taeniopteroid and equal to that of specimen MP-Pb 3577A. Secondary veins are not preserved near the midrib, in the remainder of the lamina they run at an angle of $60^{\circ}$ to the midrib until they reach the margin.

Specimen MP-Pb 3577B corresponds to the base of a leaf. It is $6.7 \mathrm{~cm}$ long and $1.66 \mathrm{~cm}$ wide (max.), gradually contracting towards the base into a short and broad stalk ( $1 \mathrm{~cm}$ maximum width). The 
stalk is composed of a bundle of thick parallel veins, which resolve in veins of secondary veining and midrib (about $4 \mathrm{~mm}$ wide) just above the beginning of the leaf lamina. Secondary veining is badly preserved, showing a similar general orientation to that verified in other specimens (about $60^{\circ}$ ).

Comparison: The specimens under consideration resemble Glossopteris dorizonenesis Rohn, Oliveira-Babinski and Rösler, G. leptoneura Bunbury, and G. stricta Bunbury in possessing narrow leaf with acute apex, but all three species are distinct from them in venation pattern (Rohn et al. 1984, Chandra and Singh 1992). At first sight, the venation pattern reminds one of that of G. taeniopteroides Feismantel sensu Kovács-Endrödy (1976), who described these African leaves with less divergent secondary veins from the undivided midvein in comparison to the Indian representatives of the species. However, here the midrib is composed of longitudinal strands (her figures exhibit this feature too, fig. 17), the shape of the leaf is entirely different, and the number of secondary veins per $\mathrm{cm}$ is higher. In terms of venation pattern, specimens here described can also be compared with $G$. damudica Feistmantel and G. nimishea Chandra and Surange (Maheshwari and Prakash 1965, Kovács-Endrödy 1976, Chandra and Singh 1992). Both species, however, are different in leaf shape, and the secondary veins are almost perpendicular to the midrib and margin. In all characters, the leaves under consideration agree closely with specimens informally described and illustrated by Broutin et al. (1995) as Glossopteris sp. 1?, except for the greater density of secondary veins. However, on account of the incompleteness and poor preservation, the present specimens have not been classified under a new formal name.

\section{DISCUSSION}

\section{Age OF FlorA}

Despite the relatively low taxonomic diversity, the floristic elements are useful for age assignment. The glossopterid leaves under consideration show some diagnostic features mostly found in leaves of West- ern Gondwana assemblages from the end of Early Permian (Kungurian) and younger ages. These features include small size, narrow shape and taeniopteroid venation pattern. In some cases, these kinds of leaves dominate Late Permian assemblages in South America (Rohn and Rösler 1989). In the Bolivian flora, the total absence of typical glossopterid leaves from both Gondwana Lower Permian (Rubigea sp. and Gangamopteris sp.) and Triassic (Yabeiella sp.; Glossopteris spp. from Pant and Pant 1987, Holmes 1992) is also remarkable. A very similar glossopterid leaf assemblage was collected in the uppermost part of the Gharif Formation, in the Arabian Peninsula (Broutin et al. 1995). This part of the Gharif Formation was dated as early Late Permian by palynology and marine fossils from underlying and overlying units. All these considerations about the glossopterid leaves studied indicate an end of Early Permian to Early Late Permian (middle through Late Permian) age for the deposition of the strata here analyzed.

The pecopterid foliage corresponds to taxa considered endemic of the Paraná Basin, in southern Brazil (see the first part of this report; Vieira et al. 2004). Pecopteris cf. P. pedrasica Read, and Pecopteris cf. P. cadeadensis Rohn and Rösler, are taxa identified with uncertainty, and will not be considered in this discussion. Pecopteris dolianitii Rohn and Rösler, the unique clearly identified species, has also been described from deposits of the Estrada Nova and Rio do Rasto formations in the Paraná Basin (Rohn and Rösler 1986). A Late Permian age (Kazanian-Tatarian) was proposed for these units based on the occurrence of: (a) Kungurian-Kazanian palynofloras in the underlying Irati and Palermo formations (Daemon and Quadros 1970, Arai 1980, Marques-Toigo 1991), and (b) Tatarian vertebrate terrestrial fauna at the top of the Rio do Rasto Formation (Barberena et al. 1985, Langer 2000). Besides Sphenophyllum spp. occurs in the lower part of the Rio do Rasto Formation (Serrinha Member - Rohn and Rösler 2000), while leaid conchostraceans are reported from the upper part. Both fossil groups are restricted to $\mathrm{Pa}$ - 


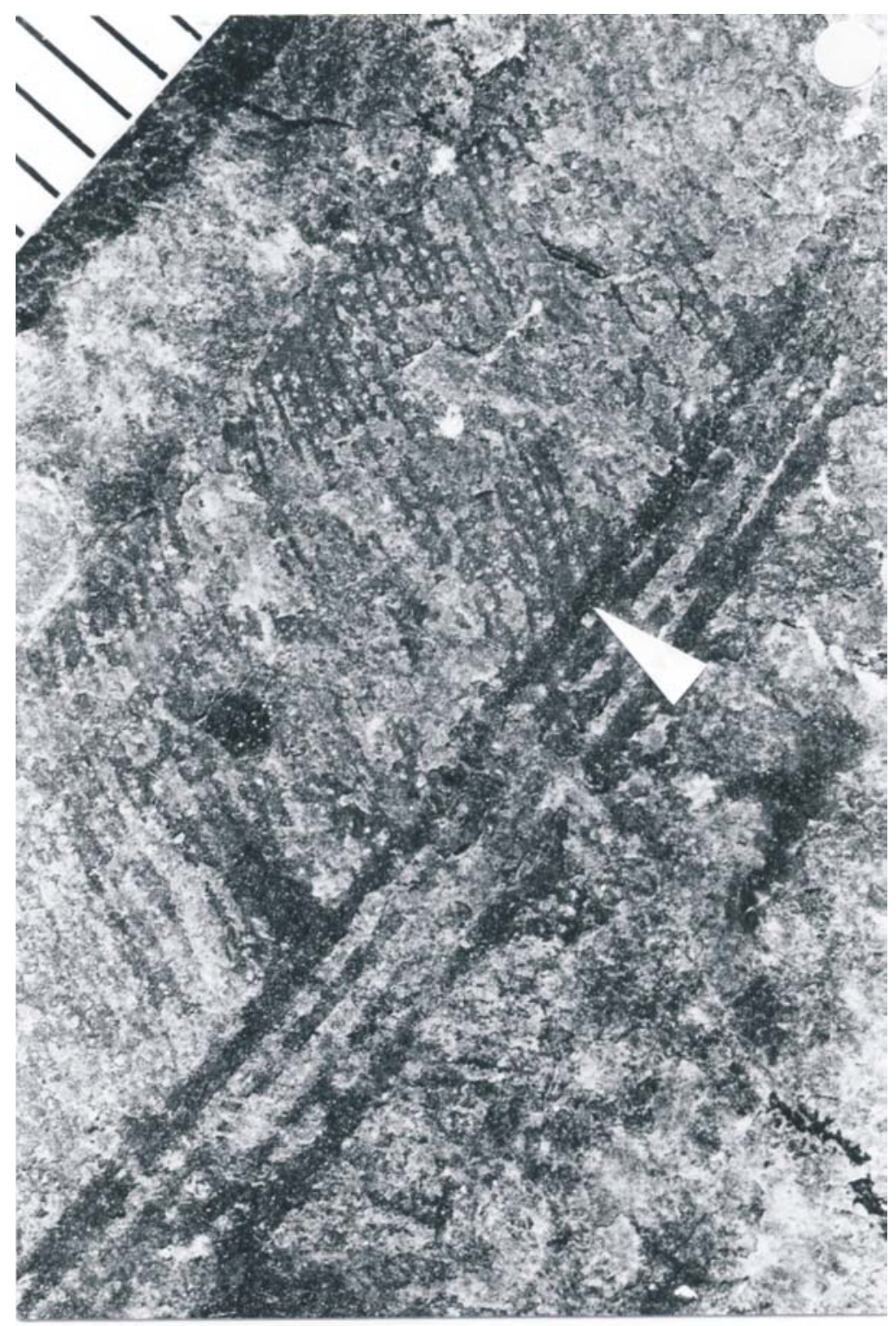

Fig. 4 - Part of the leaf illustrated in Fig. 2 (B) [MP-Pb 3577A] enlarged to show details of taeniopteroid venation (arrow). Scale bars in millimeters.

leozoic strata all over the world. In conclusion, a Late Permian age for the Chutani Formation is here proposed.

\section{PHYTOGEOGRAPHY}

Despite the relatively low taxonomic diversity, probably due to non-systematic and insufficient sampling, the composition of the floral assemblage from the Chutani Formation allows some phytogeographic discussion. The assemblage constitutes the northernmost record of "Glossopteris Flora" at the western edge of South America, considering the known distribution of this flora in Permian deposits of South America (Rohn and Rösler 1987, Archangelsky 1990). According to the current evidence, the Bolivian assemblage was a typical Gond- 
wana flora, without any Euramerican or Cathaysian elements. It includes glossopterid leaves associated with pecopterid fronds of Gondwana affinity, mostly related to endemic species from the Paraná Basin (see the first part of this report; Vieira et al. 2004). Hence, our observations suggest a shift of the northwestern boundary of the Gondwana Realm towards the tropics. The lack of information from northern South America hinders the determination of the northwestern boundary of this realm, which could be even further northwards.

An important fact is the link between Late Permian floras from the Paraná and Titicaca basins. The same type, and maybe even the same species, of glossopterid and pecopterid forms are found in both geographic areas (see Paleobotanical Results, and the first part of this report; Vieira et al. 2004), suggesting (a) the possibility of a direct dispersion route between them, and (b) the presence of similar paleoenvironmental and paleoclimatic conditions. We therefore propose that these two areas may be regarded as belonging to the same phytogeographic unit. The paleogeographic interpretation for this distribution depends on the continental configuration under consideration. In accordance with most paleomagnetic data, there are two basic Late Permian configurations proposed for Pangea: Scotese's model, the classical Pangea " $A$ " (Scotese and McKerrow 1990, Golonka et al. 1994), and Pangea " B" model (Morel and Irving 1981). The model of Scotese places each basin at a different paleolatitude, and approximately $15^{\circ}$ distant from each other. The Pangea " $\mathrm{B}$ " model assumes a paleolatitudinal proximity between both areas, more in accordance with the paleobotanic results obtained herein. The Pangea ' $\mathrm{B}$ ' configuration incorporates an anticlockwise rotation of Pangea during the Late Permian, displacing western Gondwana back to higher latitudes, and placing Bolivia and southeastern Brazil (Paraná Basin area) at a similar southern latitude (Díaz-Martínez et al. 1993, Broutin et al. 1995, Fluteau et al. 2001). The Pangea "A" model considers that most of this rotation took place later, in the Early Triassic (Golonka et al. 1994).

\section{CONCLUSIONS}

We confirm the presence of Glossopteris in the Bolivian Central Andes (west-central South America), as well as the phytogeographic extension of the Gondwana Realm towards northwestern Gondwana (northern South America). We also suggest a Late Permian age for the fossil-bearing beds of the Chutani Formation, although we do not discard the possibility of a younger (Early Triassic) age for the uppermost part of this unit, as suggested by Sempere et al. (1992). Broutin et al. (1995) suggest a wide extension of the Glossopteris Flora in the Late Permian for other regions of Gondwana (northern Africa and Arabian Peninsula) and southern Europe (Spain, Turkey). This could be due to paleoclimatic changes (more uniform global climate conditions, expansion of seasonal climates) and paleogeographic changes (anti-clockwise rotation and northward migration of Gondwana) that took place during the Late Permian (Díaz-Martínez et al. 1993, 2000, Broutin et al. 1995).

\section{ACKNOWLEDGMENTS}

We thank Yacimientos Petrolíferos Ficales Bolivianos (YPFB), Servicio Nacional de Geología y Minería de Bolivia (SERGEOMIN) and ORSTOM Bolivie for logistic support for fieldwork in Bolivia. Suggestions for improvements of the manuscript from Hermann Pfefferkorn and anonymous reviewers are gratefully acknowledged. Research that led this report was partly supported by grants from Ministerio de Educación y Ciencia de España, ORSTOM and the Petroleum Research Fund (U.S.A.), to EDM, and from Conselho Nacional de Pesquisa (CNPq) to CELV. Photos by Luiz Flávio Lopes, photographer of the Departamento de Paleontologia e Estratigrafia, IG-UFRGS. This paper is a contribution to the IGCP Project 471.

\section{RESUMO}

Plantas fósseis, pertencentes aos morfo-gêneros Glossopteris, Pecopteris e Asterotheca, foram coletadas na porção superior da seção aflorante da Formação Chutani, 
próxima ao povoado de San Pablo de Tiquina, sudeste do lago Titicaca (Altiplano norte, Bolívia). Este trabalho apresenta a primeira descrição de espécimes do morfogênero Glossopteris provenientes da Bolívia. Os espécimes estudados de Glossopteris consistem em impressões foliares pobremente preservadas nas quais feições diagnósticas estão presentes. Os fragmentos foliares apresentam venação secundária do tipo teniopteróide, uma característica típica de glossopterídeas encontradas em depósitos do Permiano Superior do Gondwana. Por sua vez, a única espécie de Pecopteris confirmada para estes níveis da Formação Chutani, i.e. P. dolianitii Rohn and Rösler (ver Vieira et al. 2004), foi previamente assinalada para estratos do Permiano Superior da Bacia do Paraná (formações Estrada Nova e Rio do Rasto). Portanto, uma idade neopermiana é tentativamente proposta para os níveis da Formação Chutani que contém a associação estudada. As implicações fitogeográficas deste novo achado são brevemente analisadas.

Palavras-chave: Altiplano Boliviano, Permiano, Glossopteris, fitogeografia.

\section{REFERENCES}

Arai M. 1980. Contribuição dos polens estriados na bioestratigrafia neopaleozóica da parte nordeste da Bacia do Paraná. Bol IG-USP 11: 98-105.

ARChANGELSKy S. 1958. Estudio geológico y paleontológico del Bajo de la Leona (Santa Cruz). Acta Geol Lilloana 2: 5-133.

ArChangelsky S. 1984. Floras Neopaleozóicas del Gondwana y su zonación estratigráfica - Aspectos paleogeográficos. Com Serv Geol Portugal 70: $135-150$.

Archangelsky S. 1986. Late Paleozoic floras of the Southern Hemisphere: distribution, composition, paleoecology. In: Gastaldo RA (Org.), Land Plants: notes for a short course, Knoxville: University of Tennessee, p. 129-142. (University of Tennessee, Studies in Geology, 15).

ArChangelsky S. 1990. Plant distribution in Gondwana during the late Paleozoic. In: TAYLOR TN AND TAYLOR EL (Eds.), Antartic Paleobiology, its role in the reconstruction of Gondwana, New York: SpringerVerlag, p. 102-117.

ARCHANGELSKY S. 1993. Consideraciones sobre las floras paleozoicas de Bolivia. Rev Téc YPFB (13/14): 167-172.
Barberena MC, Araújo DC and Lavina EL. 1985. Late Permian and Triassic tetrapods of southern Brazil. Nat Geog Res 1: 5-20.

Broutin J, Roger J, Platel JP, Angiolini L, Baud A, Bucher H, Marcoux J and Al Hasmi H. 1995. The Permian Pangea. Phytogeographic implications of new paleontological discoveries in Oman (Arabian Peninsula). C.R. Acad. Sci. Paris 321 (série IIa): 1069-1086.

Chandra S And Singh KJ. 1992. The genus Glossopteris from the Late Permian beds of Handapa, Orissa, India. Rev Palaeobot Palyn 75: 183-218.

DAEMON RF AND QuAdros LP. 1970. Bioestratigrafia do Neopaleozóico da Bacia do Paraná. In: XXIV CoNGresso Brasileiro DE Geologia, 24., Brasília. Anais..., Brasília: SBG, p. 359-412.

Díaz-Martínez E, Isaacson PE and Sablock PE. 1993. Late Paleozoic latitudinal shift of Gondwana: stratigraphic/sedimentologic and biogeographic evidence from Bolivia. Doc Lab Géol Lyon 125: 119-138.

Díaz-Martínez E, Sempere T, Isaacson PE and Grader G. 2000. Paleozoic of western Gondwana active margin (Bolivian Andes). In: INTERNATIONAL Geological Congress, 31., Rio de Janeiro. PreCongress Fieldtrip Bft 27..., Rio de Janeiro, 31p.

Feistmantel O. 1878. Palaeozoische und mesozoiche Flora des östlichen Australiens. Palaeontographica suppl. 33: 55-130.

Fluteau F, Besse J, Broutin J and Ramsteing G. 2001. The Late Permian climate. What can be inferred from climate modelling concerning Pangea scenarios and Hercynian range altitude. Paleogeography, Paleoclimatology, Paleoecology 167: 39-71.

Golonka J, Ross MI and Scotese CR. 1994. Phanerozoic paleogeographic and paleoclimatic modeling maps. In: Embry AF, BeAuchamp B AND Glass DJ (Eds.), Pangea: Global Environments and Resources: Canadian Society of Petroleum Geologists, p. 1-47. Memoir 17.

Holmes WBK. 1992. Glossopteris-like leaves from the Triassic of eastern Australia. Geophytology 22: 119-125.

KovÁCs-EndRöDY É. 1976. Notes on some Glossopteris species from Hammanskraal (Transvaal). Palaeont africana 19: 67-95. 
LANGER MC. 2000. The first record of dinocephalians in South America: Late Permian (Rio do Rasto Formation) of the Paraná Basin, Brazil. N Jb Geol Paläont Abh 215: 69-95.

Maheshwari HK. 1965. Studies in the Glossopteris Flora of India - 22. On some species of the genus Glossopteris from the Raniganj Stage of the Raniganj Coalfield, Bengal. The Palaeobotanist 13: 129-143.

Maheshwari HK and Prakash G. 1965. Studies in the Glossopteris Flora of India - 21. Plant megafossils from the Lower Gondwana exposures along Bansloi River in Rajmahal Hills, Bihar. The Palaeobotanist 13: $115-128$.

Marques-Toigo M. 1991. Palynobiostratigraphy of the southern Brazilian Neopalaeozoic Gondwana Sequence. In: International Gondwana SympoSIUM, 7., São Paulo. Proceedings..., São Paulo: IGUSP, p. 503-515.

Morel P AND Irving EC. 1981. Tentative paleocontinetal maps for the Early Phanerozoic and Proterozoic. J Geology 86: 195-198.

Pant DD and Pant R. 1987. Some Glossopteris leaves from Indian Triassic beds. Palaeontographica Abt. B 205: $165-178$.

Rigby JF. 1966. The Lower Gondwana floras of the Perth and Collie basins, western Australia. Palaeontographica Abt. B 118: 113-152.

Rigby JF, Chandra S and Surange KR. 1988. Glossopterid plant remains in the Permian of western Australia. Mem Ass Australas Palaeontols 5: 73-78.

ROHN R AND RöSLER O. 1986. Pteridófilas pecopteróides da Formação Rio do Rasto no Estado do Paraná e da Formação Estrada Nova no Estado de São Paulo (Bacia do Paraná, Permiano Superior). Bol IG-USP 17: 57-76.

ROHN R AND RöSLER O. 1987. Relações entre a flora permiana do Gondvana e as floras das províncias setentrionais. In: Congresso Brasileiro de PALEontologia, 10., Rio de Janeiro. Anais..., Rio de Janeiro: v. 2, p. 885-899.
RoHN R AND RöSler O. 1989. Novas ocorrências de Glossopteris na Formação Rio do Rasto (Bacia do Paraná, Permiano Superior). Bol IG-USP Publ Esp 7: 101-125.

Rohn R ANd Rösler O. 2000. Middle to Upper Permian phytostratigraphy of the eastern Paraná Basin. Revista Universidade de Guarulhos, Geociências no especial: 69-73.

RoHN R, BABINSKI MECBO AND RöSLER O. 1984. Glossopteris da Formação Rio do Rasto no sul do estado do Paraná. In: Congresso Brasileiro de GeoloGIA, 33., Rio de Janeiro. Anais..., Rio de Janeiro: SBG, v. 2, p. 1061-1074.

Scotese CR And McKerrow WS. 1990. Revised world maps an introduction. In: McKerrow WS AND Scotese CR (Eds.) Paleozoic Paleogeography and Biogeography, London: Geol. Soc. London, p. 121. Memoir 12.

Sempere T, Aguilera E, Doubinger J, Janvier P, Lobo J, Oller J AND Wenz S. 1992. La Formation de Vitiacua (Permien moyen à supérieur - Trias ?inférieur, Bolivie du Sud): stratigraphie, palynologie et paléontologie. N Jb Geol Paläont Abh 185: 239-253.

SuÁrez-Soruco R. 1974. Floras fósiles permocarboníferas presentes en Bolivia. Rev Téc YPFB 3: 97-102.

Vieira CEL, Iannuzzi R, Guerra-Sommer M, DíazMartinez E and Grader G. 2004. Permian plants from the Chutani Formation (Titicaca Group, Northern Altiplano of Bolivia): I. genera Pecopteris and Asterotheca. An Acad Bras Cienc 76: 117-128.

White D. 1908. Fossil Flora of the Coal Measures of Brazil. In: White IC (Resp.), Comissão de Estudos das Minas de Carvão de Pedra do Brasil III - Relatório Final, Rio de Janeiro: Serviço Geológico do Brasil, p. 337-617. 